\title{
Studi Perkembangan Pasar Tradisional Dan Toko Modern Ditinjau Dari Jarak, Aksesbilitas, Dan Perilaku Konsumen Di Kota Surakarta
}

\author{
Lestari Hidayati M, Galing Yudana, Winny Astuti \\ Program Studi Perencanaan Wilayah dan Kota \\ Jurusan Arsitektur, Fakultas Teknik \\ Universitas Sebelas Maret, Surakarta \\ Email: lestarihidayatimarfuah@yahoo.co.id
}

\begin{abstract}
The development of traditional and modern stores is determined by several factors such as distance, accessibility and consumer behavior. Since the emergence of modern stores in Surakarta, the distance between traditional markets and modern stores are of concern to the government of Surakarta, because the distance is too close location can affect the reduction in income, traders in traditional markets that will impact the sustainability of traditional markets. The second factoris the accessibility factor. The pattern of the spread of modern stores are mostly located in the city center and most are in the residential area of the middle and upper status, whereas traditional markets mostly scattered pad residential areas with medium status. This has an impact on the level of accessibility that is owned by traditional and modern stores, where modern stores willhave a high level of accessibility than traditional markets. The third factor is consumer behavior. Offers and services provided by modern stores make modern store location becomes an alternative place to shop than in the traditional market. The issue of traditional markets will be sought able competitive with modern stores by the City of Surakarta, this study wanted to know how thedevelopment of traditional and modern shops in Surakarta viewed from a distance, accessibility, and consumer behavior. The analytical method used is the analysis techniques skooring and descriptive comparative analysis. The results showed that more modern stores have the opportunity to evolve from the traditional markets. Of these three aspects, aspects of accessibility is a challenge for the traditional market for some traditional markets do not get public transport services. Aspects ofdistances and consumer behavior have the same development category.
\end{abstract}

Keywords:development, traditional markets, modern stores, distance, accessibility, consumer behavior

\section{PENDAHULUAN}

Perkembangan Pasar Tradisional dan Toko Modern ditentukan oleh beberapa faktor seperti jarak, aksesibilitas dan perilaku konsumen. Menurut Manek (2006), aspek yang dapat mempengaruhi perkembangan Pasar Tradisional meliputi:aspek kebijakan pemerintah, aspek fisik keruangan, dan aspek sosial ekonomi. Aspek kebijakan pemerintah berkaitandengan kesesuaian lokasi pendirian Pasar Tradisional dan Toko Modern dengan peraturan mintakat. Peraturan mintakat pada perkembangan Pasar Tradisional dan Toko Modern berkaitan dengan jarak. Penentuan jarak untuk sarana perdagangan ditentukan berdasarkan lokasi antar sarana perdagangan tidak saling berdekatan agar pelayanan antar satu pasar dengan pasar yang lain tidak saling tumpang tindih. Aspek jarak juga termasuk aspek fisik keruangan, dalam aspek ini juga berkaitan dengan aksesibilias, dimana aksesibilitas yang tinggi akan memberikan peluang lebih besar pada perkembangan Pasar Tradisional dan Toko Modern. Aspek sosial ekonomi merupakan aspek yang berkaitan dengan perilaku konsumen. Perilaku konsumen terhadap keberadaan Pasar Tradisional dan Toko Modern mempengaruhi perkembangan sebuah sarana perdagangan karena konsumen menjadi faktor untuk berjalanya suatu kegiatan di dalam Pasar Tradisional dan Toko Modern.

Menurut Dewar dan Vanessa (1990) suatu pasar mampu berkembang secara baik karena berada pada lokasi yang begitu dekat dengan pergerakan orang banyak, seperti daerah CBD, 
pusat/konsentrasi industri, sekitar terminal transportasi umum. Pernyataan tersebut menunjukan bahwa lokasi sebuah pasar bernilai tinggi apabila berada pada aksesibilitas yang tinggi. Berdasarkan pola penyebaran Pasar Tradisional sebagian besar berada pada kawasan CBD dengan struktur jaringan jalan arteri dan kolektor, sedangakan Pasar Tradisional tersebar pada kawasan permukiman dengan struktur jaringan jalan secara acak baik di jalan arteri, kolektor, maupun lokal. Dari pola penyebaran dapat terlihat bahwa Toko Modern cenderung lebih memiliki tingkat aksesibilitas yang tinggi daripada Pasar Tradisional.

Faktor jarak dan aksesibilitas padaToko Modern menjadi daya tarik bagi masyarakat untuk melakukan belanja di Toko Modern dan menjadikan Toko Modern sebagai alternatif lokasi belanja selain di Pasar Tradisional. Pasar Tradisional dan Toko Modern merupakan sarana perdagangan di Kota Surakarta, yang keduanya memberikan kontribusi pada pemasukan perekonomian pemerintah Kota Surakarta. Oleh karenanya, pemerintah berupaya mewujudkan perkembangan Pasar Tradisional dan Toko Modern secara bersamaan tanpa mematikan salah satu jenis sarana perdagangan dengan merumuskan suatu kebijakan perlindungan Pasar Tradisional dan penataan Toko Modern.

Tujuan dari penelitian ini adalah untuk mengetahui tingkat perkembangan Pasar Tradisional dan Toko Modern di Kota Surakarta melalui studi komparasi perkembanganyang ditinjau dari jarak, aksesibilitas, dan perilaku konsumen.

\section{METODE}

\subsection{Ruang Lingkup}

Ruang lingkup wilayah penelitian adalah Pasar Tradisional dan Toko Modern yang ada di Kota Surakarta yang tersebar pada lima kecamatan, yaitu Kecamatan Jebres, Kecamatan Laweyan, Kecamatan Pasar Kliwon, Kecamatan Serengan, dan Kecamatan Banjarsari dengan jumlah 26 Pasar Tradisional dan 12 Toko Modern.

Ruang lingkup substansi yang menjadi koridor pembahasan penelitian ini adalah melalui pendekatan kajian untuk penyelesaian penelitian yang ditetapkan sebagai berikut:

1. Konsep pengukuran perkembangan Pasar Tradisional dan Toko Modern yang tercermin secara keruangan dan kuantitatif, meliputi jarak antar pasar, kedekatan dengan pangsa pasar, ketersediaan alat transportasi, kemudahan pencapaian lokasi pasar, daya beli konsumen, kebiasaan belanja konsumen.

2. Konsep pengukuran secara kuantitatif yaitu melakukan perbandingan Pasar Tradisional dan Toko Modern berdasarkan hasil pengukuran variabel.

\subsection{Metode Analisis}

Dalam penelitian ini menggunakan pendekatan penelitian deduktif. Berdasarkan jenisnya, penelitian ini termasuk jenis penelitian survei lapangan yaitu dengan melakukan studi dan pengamatan secara langsung di Kota Surakarta. Sedangkan metode yang digunakan adalah metode kuantitatif. Penelitian kuantitatif adalah penelitian yang sudah ditentukan kejelasan unsur yang terkait dengan tujuan, pendekatan, subjek, sampel dan sumber data secara mantap dan rinci sebelum penelitian dilakukan (Sangadji, 2010). Metode kuantitatif dalam penelitian ini menggunakan penelitian skoring dan penelitian komparatif deskriptif. Menurut Ulber (2005) penelitian komparatif adalah penelitian yang membandingkan dua gejala atau lebih. Dalam penelitian ini menggunakan metode penelitian komparatif deskriptif, yaitu membandingkan variabel yang sama untuk sampel yang berbeda.

Analisis dalam penelitian ini terdiri dari empat tahapan, yaitu:

1. Analisis skoring tingkat perkembangan Pasar Tradisional berdasarkan aspek jarak, aksesibilitas dan perilaku konsumen dengan pengukuran tolok ukur tinggi, sedang, dan rendah

2. Analisis skoring tingkat perkembangan Toko Modern berdasarkan aspek jarak, aksesibilitas dan perilaku konsumen dengan pengukuran tolok ukur tinggi, sedang, dan rendah

3. Analisis komparatif deskriptif (aspek jarak, aksesibilitas dan perilaku konsumen)

4. Sintesis

\section{HASIL DAN PEMBAHASAN}

\subsection{Komparasi Aspek Jarak}

Berdasarkan analisis yang dilakukan diketahui bahwa tingkat perkembangan Pasar Tradisional dari aspek jarak antar pasar 
memiliki kategori sedang, sedangkan pada Toko Modern memiliki kategori tinggi (lihat lampiran 1 tabel penilaian aspek jarak). Pada aspek jarak antar pasar, Toko Modern mempunyai peluang untuk lebihberkembang dibandingkan dengan Pasar Tradisional. Menurut Moersid (1995) dalam Hermanto (2008) bahwapada awalnya Pasar Tradisional ini mengambil tempat di suatu ruang atau lapangan terbuka, di bawah pohon besar yang telah ada pada salah satu sudut perempatan jalan atau tempat lain yang setidaknya adalah strategis dilihat dari lokasi lingkungan yang bersangkutan. Berdasarkan pernyataan tersebut bahwa lokasi Pasar Tradisional telah mempertimbangkan unsur lokasi yang strategis, disisi lain perkembangan Toko Modern juga mencari lokasi yang strategis, oleh karenanya keberadaan Toko Modern mendirikan bangunan ritel yang berdekatan dengan Pasar Tradisional. Menurut Jendi (2012) bahwa dalam pendirian Toko Modern faktor lokasi merupakan faktor yang cukup dipertimbangkan oleh konsumen. Konsumen akan berbelanja ditempat yang strategis dan akses menuju lokasi dapat dijangkau dengan mudah. Lokasi Pasar Tradisional dan Toko Modern yang memiliki kedekatan kurang dari 500 meter didominasi di daerah pusat Kota yaitu pada Jl. Slamet Riyadi, pada kawasan tersebut merupakan pusat kegiatan di Kota Surakarta seperti pertokoan, jasa bank, pariwisata, perhotelan dll. Lokasi tersebut menarik bagi Toko Modern untuk mendirikan lokasi pusat perbelanjaan pada kawasan tersebut. Sedangkan jarak antar Toko Modern kurang dari 540 meter berada pada kawasan J1. Slamet Riyadi. Hal ini menunjukan bahwa pendirian lokasi Toko Modern terpusat pada satu titik pusat kegiatan di Kota Surakarta.

Penilaian jarak juga berdasarkan pada kedekatan dengan pangsa pasar, yaitu jarak lokasi Pasar Tradisional dan Toko Modern berada pada penggunaan lahan permukiman. Identifikasi dilakukan dengan melihat jangkauan pelayanan Pasar Tradisional dan Toko Modern merupakan kawasan permukiman. Pada aspek kedekatan dengan pangsa pasar menunjukan hasil bahwa antara Pasar Tradisional dan Toko Modern berada pada kawasan permukiman padat tinggi. Hal tersebut menjadi peluang bagi perkembangan Pasar Tradisional dan Toko Modern, karena keberadaan pangsa pasar menjadi salah satu faktor pendukung berjalanya kegiatan sebuah pasar.Berdasarkan hasil overlay peta penggunaan lahan dengan persebaran Pasar Tradisional dan Toko Modern, menunjukan bahwa secara umum persebaran Pasar Tradisional dan Toko Modern tersebar padaduakawasan, yaitu kawasan perdagangan, jasa/industri dan kawasan permukiman. Persebaran Toko Modern, terlihat sebagian besar berlokasi di pusat kota, membentuk cluster di sepanjang kawasan perdagangan dan jasa, perkantoran dan industri (seperti terlihat di sepanjang Jl.Slamet Riyadi, yang merupakan jalur arteri). Toko Modern dengan skala besar cenderung berlokasi di cluster perdagangan dan jasa, yang memiliki aksesibilitas yang tinggi dan jenis supermarket sebagian besar berada di kawasan permukiman. Untuk Pasar tradisional, sebagian besar berada di kawasan permukiman penduduk dan sisanya berlokasi pada kawasan dengan tingkat aksesibilitas yang tinggi, utamanya Pasar Tradisional skala besar. Perbandingan perkembangan Pasar Tradisional dan Toko Modern dari sisi jarak. Pada Pasar Tradisional memiliki perkembangan dengan kategori sedang (2) pada aspek jarak antar pasar dan perkembangan tinggi (3) pada aspek kedekatan dengan pangsa pasar, sehingga penilaian jarak untuk Pasar Tradisional berada pada skala tinggi. Sedangkan Toko Modern memilki perkembangan tinggi (3) pada aspek jarak antar pasar dan kedekatan dengan pangsa pasar, sehingga penilaian jarak untuk Toko Modern adalah tinggi. Dari hasil tersebut meskipun berada pada posisi perkembangan tinggi akan tetapi dari aspek jarak, Toko Modern lebih berkembang daripada Pasar Tradisional. Beberapa Pasar Tradisional yang berada pada lokasi yang berdekatan dengan Toko Modern. Oleh karenanya kebijakan terkait pembatasan jarak antara Pasar Tradisional dan Toko Modern perlu ditingkatkan ketegasan dalam tindak lanjutnya.

\subsection{Komparasi Aspek Aksesibilitas}

Perkembangan pasar dilihat dari aspek ketersediaan moda transportasi, pada Pasar Tradisional memiliki perkembangan sedang, sedangkan pada Toko Modern memiliki perkembangan tinggi (lihat lampiran 2 tabel penilaian aspek aksesibilitas). Hal tersebut menunjukan bahwa pelayanan transportasi 
umum diToko Modern lebih tinggi dibandingkan dengan Pasar Tradisional, pelayanan transportasi umum berkaitan dengan rute jalur trayek bus kota dan angkutan kota. Menurut Ma'ruf (2006) transportasi umum yang banyak melintas di depan pusat perbelanjaan atau pertokoan akan memberikan konsumen untuk masuk ke area perbelanjaan. Adanya jalur trayek yang melewati Pasar Tradisional dan Toko Modern akan memberikan kesempatan konsumen lebih banyak masuk ke area pasar.

Pelayanan transportasi umum di Kota Surakarta mengarah pada pusat kegiatan. Pusat kegiatan di Kota Surakarta berada pada Jl. Slamet Riyadi, hal ini menjadikan pelayanan transportasi dengan bus dan angkutan kota baik di Pasar Tradisional dan Toko Modern mengelompok pada kawasan tersebut. Selain itu, meskipun Pasar Panggungrejo berada pada pinggiran kota, akan tetapi pasar tersebut juga terlayani oleh kedua jenis transportasi umum tersebut, hal ini dikarenakan selain terdapat sarana perdagangan pada kawasan tersebut juga diperuntukan sebagai kawasan pendidikan perguruan tinggi. Pasar yang tidak dilewati oleh transportasi umum dipengaruhi oleh faktor lokasi. Jalur trayek terpusat pada pusat kota dan mengarah keluar menghubungkan dengan kawasan sekitar Kota Surakarta, oleh karenanya Pasar Tradisional yang berada di pinggiran kota tidak memiliki akses transportasi umum. Persebaran Toko Modern di Kota Surakara cenderung mengikuti struktur jaringan jalan. Struktur jaringan jalan di Kota Surakarta memiliki pola menjari ke arah barat. Dengan kondisi ini, maka lokasi Toko Modern yang sangat tergantung pada faktor aksesibilitas cenderung untuk berlokasi di kawasan barat Kota Surakarta, khususnya di Kecamatan Banjarsari dan Kecamatan Laweyan. Pola yang terjadi adalah untuk Toko Modern cenderung berada di sepanjang jaringan jalan arteri dan kolektor, sebaliknya untuk Pasar Tradisional, sebaran lokasi menunjukan pola yang acak (dari jaringan jalan arteri hingga lokal dan lingkungan). Kemudahan pencapaian suatu lokasi dihubungkan dengan lokasi lainnya lewat jaringan transportasi yang ada, berupa prasarana jalan dan alat angkut yang bergerak diatasnya. Mudah atau sulitnya lokasi-lokasi tersebut dicapai melalui sistem jaringan transportasinya, merupakan hal yang subjektif, kualitatif, dan relatif (Tamin, O.Z., 1997: dalam Miro: 2005). Oleh karenanya ukuran kemudahan ketersediaan moda transportasi didasarkan pada kemudahan pencapaian lokasi dan waktu tempuh pencapaian lokasi pasar.

Berdasarkan hasil analisis pencapaian menuju lokasi Pasar Tradisional dan Toko Modern menunjukan perkembangan sedang. Kemudahan pencapaian lokasi diukur berdasarkan pola pergerakan konsumen dengan menggunakan transportasi umum dari daerah asal ke daerah tujuan (pasar). Kemudahan pencapaian menuju lokasi pasar, berkaitan dengan keterpaduan pelayanan transportasi dengan sarana perdagangan yang ada. Keterpaduan transportasi umum merupakan tujuan dan sasaran pemerintah Kota Surakarta dalam mewujudkan penyelenggaraan transportasi yang efektif. Efektif dalam hal ini salah satunya adalah mudah dicapai dan memiliki keterpaduan atau integrated. Mudah dicapai artinya bahwa pelayanan menuju ke tempat tujuan mudah bagi masyarakat pengguna jasa; keterpaduan yaitu terwujudnya keterpaduan antar dan intermoda dalam jaringan prasarana dan pelayanan (dokumen TRATALOK, pada Tahun Anggaran 2009). Waktu tempuh untuk mencapai Pasar Tradisional dan Toko Modern di Kota Surakarta tergolong sedang. Pada Pasar Tradisional mayoritas konsumen membutuhkan waktu kurang dari 10 menit, karena lokasi persebaran Pasar Tradisional tersebar secara merata pada masing-masing kecamatan, sehingga masyarakat memiliki jarak yang cukup dekat dengan lokasi Pasar Tradisional. Sedangkan pada Toko Modern, lokasi Toko Modern cenderung berada pada pusat kota dengan penggunaan lahan sekitar Toko Modern didominasi oleh perkantoran dan pertokoan, sedangkan permukiman berada agak jauh dengan Toko Modern, disisi lain konsumen Toko Modern tidak hanya berasal dari masyarakat Kota Surakarta akan tetapi juga berasal dari luar daerah Kota Surakarta sehingga mayoritas konsumen membutuhkan waktu lebih dari 15 menit. Hal tersebut menunjukan waktu tempuh menuju Pasar Tradisional lebih singkat daripada waktu tempuh menuju Toko Modern. Aksesibilitas merefleksikan jarak perpindahan di antara beberapa tempat yang dapat diukur dengan waktu dan/atau biaya yang dibutuhkan untuk perpindahan tersebut. Tempat yang memiliki 
waktu dan biaya perpindahan yang rendah menggambarkan adanya aksesibilitas yang tinggi (Manek, 2006). Peningkatan fungsi transportasi akan meningkatkan aksesibilitas karena dapat menekan waktu dan biaya yang dibutuhkan.Perbandingan pernilaian aksesibilitas pada Pasar Tradisional dan Toko Modern, ditentukan berdasarkan pada kompilasi nilai antara ketersediaan alat transportasi dan kemudahan pencapaian lokasi. Pasar Tradisional memiliki nilai sedangpada aspek ketersediaan moda transportasi dan kemudahan pencapaian lokasi, sehingga penilaian aksesibilitas untuk Pasar Tradisional berada pada kategori sedang. Sedangkan Toko Modern memperoleh nilai sedang pada aspek ketersediaan moda transportasi dan nilai tinggi pada aspek kemudahan pencapaian lokasi , sehingga penilaian aksesibilitas untuk Toko Modern adalah tinggi.

\subsection{Komparasi Aspek Perilaku Konsumen}

Aspek perilaku konsumen dalam penelitian ini dilihat berdasarkan kebiasaan belanja konsumen yaitu intensitas konsumen pergi ke Pasar Tradisional dan Toko Modern, serta daya beli konsumen, yaitu tingkat pengeluaran biaya belanja setiap bulan baik di Pasar Tradisional maupun Toko Modern.

Berdasarkan hasil analisis diketahui bahwa kebiasaan belanja konsumen di Toko Modern dan Pasar Tradisional memiliki kategori sedang (lihat lampiran 3 tabel penilaian aspek perilaku konsumen). Masyarakat Kota Surakarta sebagai konsumen di Pasar Tradisional dan Toko Modern cenderung tidak memihak pada salah satu pusat perbelanjaan. Konsumen menjadikan Pasar Tradisional dan Toko Modern sebagai lokasi perbelanjaan yang saling melengkapi. Berdasarkan kebutuhan jenis barangnya intensitas konsumen pergi ke Pasar Tradisional lebih tinggi jika dibandingkan dengan Toko Modern yang dilakukan setiap 1-2 minggu sekali. Penilaian daya beli konsumen padaPasar Tradisional dan Toko Modern memiliki perkembangan dengan kategori sedang. Menurut Mursid (1997) daya beli merupakan faktor yang dapat mengubah keinginan menjadi permintaan. Kawasan yang memiliki daya beli yang baik/tinggi merupakan salah satu faktor yang potensial dalam mengoptimalkan fungsi pasar (Manek, 2006).
Perbandingan penilaian perilaku konsumen pada Pasar Tradisional dan toko modern, ditentukan berdasarkan pada kompilasi nilai antara kebiasaan belanja dan daya beli konsumen. Pasar Tradisional memiliki nilai sedang pada aspek kebiasaan belanja dan daya beli, sehingga penilaian perilaku konsumen untuk Pasar Tradisional berada pada skala sedang. Sedangkan Toko Modern memperoleh nilai sedang pada aspek aspek kebiasaan belanja dan daya beli, sehingga penilaian aksesibilitas untuk Toko Modern adalah sedang.

\section{KESIMPULAN}

Berdasarkan penilaian dari ketiga aspek yang mempengaruhi perkembangan Pasar Tradisional dan Toko Modern menunjukan bahwa Toko Modern lebih memiliki peluang untuk berkembang daripada Pasar Tradisional. Hasil analisis menunjukan bahwa Pasar Tradisional berada pada kategori perkembangan sedang dengan nilai 7 , sedangkan Toko Modern memiliki kategori perkembangan tinggi dengan nilai 8 (lihat lampiran 4 tabel komparasi pasar tradisional dan toko modern).

Dari ketiga aspek tersebut, aspek jarak dan perilaku konsumen memiliki kategori perkembangan yang sama.Sedangkan aspek aksesibilitas pada Pasar Tradisional memiliki nilai yang lebih rendah daripada toko modern, oleh karenanya aspek aksesbilitas menjadi tantangan bagi perkembangan Pasar Tradisional karena beberapa Pasar Tradisional tidak mendapatkan pelayanan transportasi umum.

\section{REFERENSI}

Dewar, D.dan V. Watson.1990. Urban Market Developing Informal Retailing. London: Rontledge.

Dokumen Tatralok, DISHUBKOMINFO Surakarta(pada tahun anggaran 2009).

Hermanto, H.. 2008. Faktor-Faktor Yang Berpengaruh Terhadap Perubahan Fungsi Ruang di Serambi Pasar Induk Wonosobo. Magister Teknik Arsitektur. Universitas Diponegoro, Semarang

Jendi, R.. 2012. Analisis Faktor-faktor yang Mempengaruhi Perilaku Konsumen Berbelanja Supermarket di Kota Padang. Universitas Negeri Padang 
Manek, V.M.. 2006. Kajian Faktor-Faktor Yang Mempenegrauhi Tidak Optimalnya Fungsi Pasar Tradisional Lolowa dan Pasar Tradisional Fatubenao Kecamatan Kota Atambua, Kabupaten Belu. Magister Pembangunan Wilayah dan Kota.Universitas Diponegoro, Semarang

Ma'ruf, H..2006. Pemasaran Ritel. Jakarta: Gramedia Pustaka Utama

Miro, F.. 2005. Perencanaan Transportasi. Jakarta: Erlangga

Mursid, M.. 1997. Manajemen Pemasaran. Jakarta: Penerbit Bumi Aksara

Sangadji, Mamang. 2010. Metodologi Penelitian: Pendekatan Praktis dalam Penelitian. Yogyakarta: Andi.

Ulber. S..2005. Metode Penelitian Sosial. Bandung: Unpar Press. 


\section{LAMPIRAN}

\section{Lampiran 1 Penilaian Aspek Jarak}

\begin{tabular}{|l|c|c|c|c|}
\hline \multicolumn{1}{|c|}{ Parameter } & $\begin{array}{c}\text { Pasar } \\
\text { Tradisional }\end{array}$ & Kategori & $\begin{array}{c}\text { Toko } \\
\text { Modern }\end{array}$ & Kategori \\
\hline Jarak antar pasar & 45 & Sedang & 30 & Tinggi \\
\hline $\begin{array}{l}\text { Kedekatan dengan } \\
\text { pangsa pasar }\end{array}$ & 75 & Tinggi & 33 & Tinggi \\
\hline
\end{tabular}

Sumber: Analisis Penulis, 2016

\section{Lampiran 2 Penilaian Aspek Aksesibilitas}

\begin{tabular}{|l|c|c|c|c|}
\hline \multicolumn{1}{|c|}{ Parameter } & $\begin{array}{c}\text { Pasar } \\
\text { Tradisional }\end{array}$ & Kategori & $\begin{array}{c}\text { Toko } \\
\text { Modern }\end{array}$ & Kategori \\
\hline $\begin{array}{l}\text { Ketersediaan Moda } \\
\text { Transportasi }\end{array}$ & 57 & Sedang & 29 & Tinggi \\
\hline $\begin{array}{l}\text { Keandalan } \\
\text { Ketersediaan Moda } \\
\text { Transportasi }\end{array}$ & 290 & Sedang & 284 & Sedang \\
\hline Waktu tempuh & 389 & Sedang & 288 & Sedang \\
\hline
\end{tabular}

Sumber: Analisis Penulis, 2016

\section{Lampiran 3 Penilaian Aspek Perilaku Konsumen}

\begin{tabular}{|l|c|c|c|c|}
\hline \multicolumn{1}{|c|}{ Parameter } & $\begin{array}{c}\text { Pasar } \\
\text { Tradisional }\end{array}$ & Kategori & $\begin{array}{c}\text { Toko } \\
\text { Modern }\end{array}$ & Kategori \\
\hline $\begin{array}{l}\text { Intensitas pergi ke } \\
\text { pasar }\end{array}$ & 312 & Sedang & 286 & Sedang \\
\hline Daya beli konsumen & 325 & Sedang & 348 & Sedang \\
\hline
\end{tabular}

Sumber: Analisis Penulis, 2016

\section{Lampiran 4 Komparasi Pasar Tradisional dan Toko Modern}

\begin{tabular}{|c|c|c|c|c|c|c|}
\hline \multirow{2}{*}{ No. } & \multirow{2}{*}{ Sub Variabel } & \multicolumn{2}{|c|}{$\begin{array}{l}\text { Hasil Skooring Aspek } \\
\text { Pembanding }\end{array}$} & \multirow{2}{*}{ Variabel } & \multicolumn{2}{|c|}{ Penilaian Variabel } \\
\hline & & $\begin{array}{c}\text { Pasar } \\
\text { Tradisional }\end{array}$ & Toko Modern & & $\begin{array}{c}\text { Pasar } \\
\text { Tradisional }\end{array}$ & Toko Modern \\
\hline 1 & Jarak antar pasar & Sedang (2) & Tinggi (3) & \multirow[b]{2}{*}{ Jarak } & \multirow[b]{2}{*}{ Tinggi (3) } & \multirow[b]{2}{*}{ Tinggi (3) } \\
\hline 2 & $\begin{array}{l}\text { Kedekatan } \\
\text { dengan pangsa } \\
\text { pasar }\end{array}$ & Tinggi (3) & Tinggi (3) & & & \\
\hline 3 & $\begin{array}{l}\text { Ketersediaan } \\
\text { moda } \\
\text { transportasi }\end{array}$ & Sedang (2) & Tinggi (3) & \multirow{2}{*}{ Aksesibilitas } & \multirow{2}{*}{ Sedang (2) } & \multirow{2}{*}{ Tinggi (3) } \\
\hline 4 & $\begin{array}{l}\text { Kemudahan } \\
\text { pencapaian } \\
\text { lokasi }\end{array}$ & Sedang (2) & Sedang (2) & & & \\
\hline
\end{tabular}


Arsitektura, Vol. 14, No.2, Oktober 2016

\begin{tabular}{|c|l|c|c|l|c|c|}
\hline 5 & $\begin{array}{l}\text { Kebiasaan } \\
\text { belanja }\end{array}$ & Sedang (2) & Sedang (2) & $\begin{array}{l}\text { Perilaku } \\
\text { Konsumen }\end{array}$ & Sedang (2) & Sedang (2) \\
\hline 6 & Daya beli & Sedang (2) & Sedang (2) & Sedang (7) & Tinggi (8) \\
\hline \multicolumn{3}{|c|}{ Jumlah } \\
\hline
\end{tabular}

Sumber: Analisis Penulis, 2016 